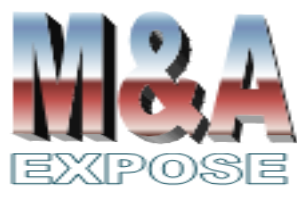

http://jurnal.usahid.ac.id/index .php/accounting
${ }^{1}$ Fakultas Ekonomi

Universitas Sahid

trieshandrimaniamain@gmail.com

\section{Analisis Determinan Minat Mahasiswa Berkarir Menjadi Akuntan Publik}

\author{
Tries Handriman Jamain ${ }^{1}$
}

\section{Abstrak}

Tujuan penelitian ini adalah untuk menganalisis faktor-faktor yang mempengaruhi minat mahasiswa akuntansi dalam pemilihan karir sebagai akuntan publik. Faktor-faktor yang mempengaruhi minat pemilihan karir sebagai akuntan publik diukur dengan variabel nilai intrinsik pekerjaan, penghasilan, pertimbangan pasar kerja, dan lingkungan kerja. Sampel sejumlah 200 responden mahasiswa Fakultas Ekonomi di tiga Perguruan Tinggi Swasta di Jakarta. Teknik analisis data menggunakan analisis regresi linier berganda. Hasil uji hipotesis secara parsial menyatakan bahwa variabel nilai intrinsik dan pertimbangan pasar kerja berpengaruh signifikan terhadap minat pemilihan karir sebagai akuntan publik, sedangkan variabel penghasilan dan lingkungan kerja tidak berpengaruh signifikan terhadap minat pemilihan karir sebagai akuntan publik. Adapun secara simultan, variabel nilai intrinsik pekerjaan, penghasilan, pertimbangan pasar kerja, dan lingkungan kerja berpengaruh positif signifikan terhadap minat pemilihan karir sebagai akuntan publik.

Kata kunci : nilai intrinsik pekerjaan, penghasilan, pertimbangan pasar kerja, lingkungan kerja.

\section{Abstract}

The purpose of this study is to analyze the factors that influence the interest of accounting students in choosing careers as public accountants. The factors that influence the interest in choosing a career as a public accountant are measured by the variable intrinsic value of work, income, labor market considerations, and work environment. A sample of 200 respondents from the Faculty of Economics students at three Private Universities in Jakarta. The data analysis technique uses multiple linear regression analysis. The results of the partial hypothesis test state that the intrinsic value and the labor market consideration variable significantly influence the interest in career selection as a public accountant, while the income and work environment variable do not significantly influence the interest in career choice as a public accountant. As for simultaneously, the variables of intrinsic value of work, income, labor market considerations, and work environment have a significant positive effect on the interest in choosing a career as a public accountant.

Keywords : intrinsic value of work, income, labor market considerations, work environment. 


\section{PENDAHULUAN}

Karir merupakan salah satu aspek yang sangat penting bagi manusia untuk menunjang kehidupannya dimasa yang akan datang, oleh karenanya karir seseorang berkontribusi besar bagi diri dan merupakan inti dari nilai dasar dan tujuan hidup seseorang.

Pesatnya perkembangan dunia bisnis dan tingginya tingkat kompetitif yang terjadi dalam menghadapi MEA (Masyarakat Ekonomi ASEAN) sehingga berdampak pada terbukanya lapangan pekerjaan yang beragam untuk angkatan kerja. Salah satu yang tergolong dalam angkatan kerja tersebut adalah sarjana ekonomi khususnya dari jurusan akuntansi. Peranan profesi akuntan sangat penting dalam perkembangan dunia bisnis dan menentukan laju perkembangan ekonomi di dunia ini, karena opini dari seorang akuntan sangat mempengaruhui dalam pengambilan keputusan bagi pemakai laporan keuangan dan pihak-pihak yang memerlukan laporan keuangan yaitu pimpinan atau manejer, investor, kreditur, bank dan pemerintah. Pemilihan karir yang tepat sesuai minat dan bakat yang dimiliki seseorang merupakan tahapan awal dalam pembetukan karir. Dalam dunia kerja, salah satu profesi yang dapat dipilih oleh sarjana akuntansi adalah profesi sebagai akuntan. Lulusan sarjana yang lebih berkualitas, mahasiswa dituntut memiliki kemampuan (skill) dan pengetahuan (knowledge) yang lebih dalam dunia kerja. Kemampuan dan pengetahuan yang dibutuhkan juga bergantung pada karir atau profesi yang akan dipilih. Karir dalam bidang akuntansi cukup luas antara lain akuntan publik, akuntan perusahaan, akuntan pendidik dan akuntan pemerintah (Setiawan, 2012). Sarjana akuntansi paling tidak mempunyai tiga alternatif langkah yang dapat ditempuh. Pertama, setelah menyelesaikan pendidikan ekonomi jurusan akuntansi, seseorang dapat langsung bekerja. Kedua, melanjutkan pendidikan akademik jenjang Strata-2. Ketiga, melanjutkan pendidikan profesi untuk menjadi akuntan publik.

Kegiatan utama dari profesi akuntan publik terutama pada kegiatan audit yang bertujuan untuk memberikan pendapat kewajaran terhadap laporan keuangan yang dibuat oleh pihak manajemen. Profesi akuntan sangat berperan penting dalam dunia bisnis. Didalam bisnis, profesi akuntan memiliki tempat yang istimewa. Seperti halnya dengan profesi-profesi lainnya, profesi akuntan dituntut harus memiliki keahlian lebih dalam pada bidang akuntansi. Tidak hanya itu, profesi akuntan dituntut untuk mampu bertindak secara profesional sesuai dengan etika profesionalisme audit. Hal tersebut dikarenakan profesi akuntan mempunyai tanggungjawab terhadap apa yang diperbuat baik terhadap pekerjaannya, organisasinya, masyarakat dan dirinya sendiri. Harris dan Djamhuri (2011) menyatakan Profesi Akuntan adalah pekerjaan yang tidak hanya berhubungan dengan pemenuhan kebutuhan hidup semata, tetapi juga memerlukan standar-standar kualitas, kode etik profesi sehingga integritas profesi akuntan senantiasa terjaga, dan akuntan semestinya senantiasa menjaga hubungan baik dengan lingkungan masyarakat disekitarnya. Terdapat beberapa macam profesi akuntan jika dilihat dari pekerjaan yang dilakukannya yaitu akuntan publik, akuntan pemerintah, akuntan manajemen dan akuntan pendidik. Masing-masing dari cabang profesi akuntan tersebut memiliki peran dan tanggung jawab yang berbeda-beda.

Pendidik juga merupakan faktor yang membentuk minat karir seseorang. Salah satu tugas pendidik akuntansi adalah untuk menghasilkan profesional-profesional di bidang akuntansi yang berkualitas dan siap bersaing di dunia kerja. Agar mahasiswa lulusan perguruan tinggi negeri maupun perguruan tinggi swasta dapat berkiprah di dunia kerja 
sesuai minat karir yang akan dipilihnya. Praktik bisnis saat ini tidak hanya menuntut keahlian akademik, mahasiswa diharapkan memiliki keahlian diluar keahlian akademik seperti pengatahuan luar dan soft skill yang tidak mahasiswa dapatkan dalam bangku kuliah. Agar dapat mencapai tujuan tersebut maka desain pendidikan akuntansi harus relevan terhadap dunia kerja, khususnya dunia kerja bagi sarjana akuntansi.

Banyaknya lulusan dari Universitas-universitas yang terbaik tidak lagi memilih berkarir di bidang akuntan publik (Widiatami, 2013), karena tingkat kesulitan dan bahkan tingkat kemampuan dan keahlian masing masing mahasiswa berbeda tidak menutup kemungkinan mereka akan berkarir di luar bidang akuntansi lainnya yang mungkin masih berhubungan dengan keuangan seperti wirausaha, konsultan keuangan.

Lulusan di bidang akuntansi dapat bekerja di berbagai bidang, diantaranya seperti berkarir sebagai akuntan publik, berkarir sebagai akuntan pendidik, berkarir sebagai akuntan perusahaan, berkarir sebagai akuntan pemerintah. Bahkan lulusan akuntansi juga dapat berkarir di luar bidang akuntansi bila memiliki bakat dan keahlian dibidang lain seperti berkarir sebagai marketing product atau bahkan menciptakan lapangan kerja sendiri. Saat ini banyak lulusan terdidik mulai melirik jalur karir lain tidak sesuai dengan bidangnya untuk mereka jalankan nantinya karena sangat tingginya tingkat persaingan dan perubahan minat karir seseorang.

Jurusan akuntansi merupakan salah satu jurusan yang paling banyak diminati oleh mahasiswa saat ini. Sulistiani (2012) menyebutkan bahwa rata-rata mahasiswa memilih jurusan akuntansi, didorong oleh keinginan mereka untuk menjadi profesional dibidang akuntansi. Pengajaran akuntansi sejak di bangku Sekolah Menengah Atas (SMA) sampai keperguruan tinggi telah didesain mengarahkan mahasiswa untuk menjadi akuntan publik. Namun pada kenyataannya tidak banyak sarjana akuntansi yang dapat berkarir sebagai akuntan publik padahal saat ini sudah terdaftar sebanyak 203 Kantor Akuntan Publik di OJK (Otorisasi Jasa Keuangan), sehingga potensi akuntan publik di Indonesia sangatlah besar. Hal ini didorong oleh jumlah perusahaan yang mencapai puluhan ribu. Setiap perusahaan membutuhkan jasa akuntan publik untuk memeriksa laporan keuangan.

Dalam pemilihan karir tentunya haruslah didasari oleh minat dan rencana karir. Minat dan rencana karir mahasiswa akuntansi akan sangat berguna bagi akademisi dalam mendesain kurikulum dan proses belajar mengajar yang lebih efektif sesuai dengan pilihan profesi mahasiswa (Kuningsih, 2013). Misalnya dengan mengadakan penjurusan mahasiswa akuntansi sesuai dengan minat berkarirnya. Kemudian pihak akademisi dapa tmemberikan fasilitas yang menunjang untuk mengembangkan dan menunjang karir tersebut, oleh karena itu diperlukan satu stimulasi untuk membuat mahasiswa mulai memikirkan secara serius tentang karir yang diinginkannya sejak masih dibangku kuliah agar mahasiswa dapat memanfaatkan waktu dan fasilitas kampus secara optimal (Widyasari, 2010). Berbicara tentang minat pemilihan karir khususnya karir yang ditawarkan oleh jurusan akuntansi yakni salah satunya sebagai akuntan, pastinya semua mahasiswa akuntansi mempunyai minat terhadap pilihan karir tersebut. Dalam pemilihan karir tersebut, mahasiswa akuntansi memiliki banyak pertimbangan untuk menentukan apakah karir tersebut merupakan karir yang terbaik yang dapat diambilnya atau tidak. Menurut Rahayu dkk, (2003) faktor-faktor yang mempengaruhi minat tersebut adalah penghargaan finansial, pelatihan professional, nilai-nilai sosial, lingkungan kerja, pertimbangan pasar kerja dan personalitas. Dalam penelitian kali ini diteliti mengenai beberapa faktor yang mempengaruhi minat mahasiswa akuntansi untuk berkarir menjadi akuntan publik, faktor-faktor tersebut 
yaitu nilai intrinsik pekerjaan, penghasilan, pertimbangan pasar kerja, dan lingkungan kerja. Sebagai seorang fresh graduate tentunya akan mempertimbangkan beberapa faktor tersebut sebelum memilih profesi sebagai akuntan publik.

Seiring dengan diberlakukannya UU No. 5 tahun 2011 yang menyatakan bahwa, para sarjana non akuntansi dapat berprofesi sebagai akuntan publik asalkan lulus ujian sertifikasi. Hal tersebut berarti bahwa dapat mengancam para lulusan jurusan akuntansi, dimana untuk menjadi akuntan publik mereka para lulusan dari jurusan akuntansi harus bersaing dengan lulusan dari jurusan non akuntansi. Hal ini disebabakan karena pertumbuhan akuntan di indonesia sangat lambat. Sampai dengan saat ini indonesia sangat kekurangan tenaga professional akuntan publik. Jumlah wajib audit yang ada di Indonesia seiring makin meningkatnya ekonomi dan munculnya perusahaan-perusahaan/lembaga baru serta makin berkembangnya perusahaan/lembaga yang sudah ada. Hal ini sangat tidak sebanding dengan jumlah akuntan publik yang ada. Padahal akuntan publik sangat berperan penting dan strategis bagi perusahaan swasta dan lembaga public lainnya. Akuntan Publik sangat menentukan kualitas laporan keuangan yang akan berkontribusi pada penetapan kebijakan-kebijakan keuangan yang pada akhirnya dapat berpengaruh pada perekonomian negara.

Berdasarkan latar belakang tersebut, penelitian ini akan menganalisis pengaruh nilai intrinsik, penghasilan, pertimbangan pasar kerja, dan lingkungan kerja terhadap minat maahsiswa berkarir menjadi akuntan publik.

\section{TINJAUAN PUSTAKA}

Minat. Dalam Theory of Reasoned Action diuraikan bahwa minat dipengaruhi oleh sikap dan norma subyektif yang dihubungkan. Keyakinan terhadap manfaat suatu kegiatan atau hal tertentu akan menimbulkan sikap positif terhadap kegiatan atau hal tersebut. Sikap positif akan mempengaruhi minat seseorang untuk melakukan kegiatan tersebut. Sikap ini merupakan hasil pertimbangan untung dan rugi dari perilaku tersebut. Di samping itu juga dipertimbangkan pentingnya konsekuensi yang akan terjadi bagi individu. Komponen berikutnya mencerminkan dampak dari norma subjektif. Norma sosial mengacu pada keyakinan seseorang terhadap bagaimana dan apa yang dipikirkan orang yang dianggapnya penting dan motivasi seseorang untuk mengikuti pikiran tersebut. Belly (2006) menyatakan bahwa minat adalah keinginan yang didorong suatu keinginan setelah melihat, mengamati dan membandingkan serta mempertimbangkan dengan kebutuhan yang diinginkannya.

Model Theory of Reasoned Action dapat digunakan sebagai alat evaluasi mengenai sikap dan perilaku secara ilmiah, yaitu untuk memperoleh konsistensi antara sikap, minat berperilaku dan perilaku yang mengacu pada nilai dan norma dalam kelompok sosial, sebagai indikator penting untuk memprediksikan perilaku yang akan diukur. Dengan demikian minat terkait pengetahuan awal mengenai aspek sosial dan antropologis, karena cara budaya menghubungkan sikap, minat dan perilaku sangat penting.

Kantor Akuntan Publik. Kantor akuntan publik (KAP) adalah badan usaha yang didirikan berdasarkan ketentuan peraturan perundang-undangan dan mendapatkan izin usaha berdasarkan undang-undang (Undang-Undang No. 5 Tahun 2011 pasal 1). Keberadaan Kantor Akuntan Publik (KAP) menjadi wadah akuntan publik untuk memberikan opini tentang hasil audit laporan keuangan suatu perusahaan. 
Profesi Akuntan Publik Menurut Undang-Undang Republik Indonesia No. 5 Tahun 2011 pasal 1 menyatakan "Akuntan Publik adalah seseorang yang telah memperoleh izin untuk memberikan jasa sebagaimana diatur dalam Undang-Undang ini". Syarat untuk menjadi Akuntan Publik berasarkan Undang- Undang No. 5 Tahun 2011 pasal 6 ayat 1 adalah sebagai berikut :

1. Memiliki sertifikat tanda lulus ujian profesi akuntan publik yang sah.

2. Berpengalaman praktik memberikan jasa akuntansi.

3. Berdomisili di wilayah Negara Kesatuan Republik Indonesia.

4. Memiliki Nomor Pokok Wajib Pajak.

5. Tidak pernah dikenai sanksi administratif berupa pencabutan izin Akuntan Publik.

6. Tidak pernah dipidana yang telah mempunyai kekuatan hukum tetap karena melakukan tindak pidana kejahatan yang diancam dengan pidana penjara 5 (lima) tahun atau lebih

7. Menjadi anggota Asosiasi Profesi Akuntan Publik yang ditetapkan oleh Menteri, dan

8. Tidak berada dalam pengampunan.

Nilai Intrinsik Pekerjaan. Intrinsik pekerjaan merupakan kepuasan yang diterima oleh individu saat atau sesudah ia melakukan pekerjaan yang disebabkan oleh faktor penghargaan, kesempatan mendapatkan promosi, tanggung jawab pekerjaan, tantangan intelektual dan pelatihan (Sulistyani, 2012). Jadi faktor nilai intrinsik pekerjaan erat kaitannya dengan kepuasan yang diterima oleh individu yang bersangkutan saat atau sesudah ia melakukan pekerjaannya. Kepuasan kerja merupakan perasaan menyenangkan terhadap pekerjaannya dan mencerminkan keberhasilan atas pekerjaan yang telah dilakukannya. Kepuasan kerja dapat tercapai apabila individu yang bersangkutan memiliki moral kerja, kedisiplinan dan prestasi kerja yang baik. Kepuasan dalam pekerjaan adalah kepuasan kerja yang dinikmati dalam pekerjaan dengan memperoleh pujian hasil kerja, penempatan, perlakuan, dan suasana lingkungan kerja dalam pekerjaaan akan lebih mengutamakan pekerjaannya daripada balas jasa yang akan diterimanya walaupun balas jasa itu penting.

Penghasilan. Penghasilan yang diperoleh dari pekerjaan yang telah dikerjakan diyakini bagi sebagian perusahaan merupakan daya tarik utama dalam memberkan kepuasan kepada karyawannya. Penghasilan yang rasional menjadi kebutuhan yang mendasar bagi pemenuhan kepuasan kerja pada setiap karyawan. Pemberian penghasilan yang layak dan adil kepada karyawan akan memberikan suasana kerja yang menyenangkan dan dapat menimbulkan motivasi kerja yang baik bagi karyawan. Adapun faktor-faktor yang mempengaruhi besarnya penghargaan antara lain sebagai berikut (Sulistyani, 2012) :

1. Penawaran dan permintaan tenaga kerja

Jika pencari kerja (penawaran) lebih banyak daripada lowongan pekerjaan (permintaan), maka penghargaan sedikit. Sebaliknya jika pencari kerja lebih sedikit daripada lowongan pekerjaan, maka penghargaan substansi semakin.

2. Kemampuan dan kesediaan organisasi

Jika kemampuan dan kesediaan organisasi untuk membayar semakin baik, maka tingkat penghargaan akan semakin meningkat. Sebaliknya jika kemampuan dan kesediaan organisasi untuk membayar semakin berkurang, maka tingkat penghargaan akan semakin menurun.

3. Organisasi karyawan

Jika organisasi karyawan kuat dan berpengaruh, maka tingkat penghargaan semakin besar. Sebaliknya jika organisasi karyawan tidak kuat dan kurang berpengaruh, maka tingkat penghargaan relatif kecil. 
4. Produktifitas kerja karyawan

Jika produktivitas kerja karyawan baik dan optimal, maka penghargaan akan semakin besar. Sebaliknya jika produktivitas kerja karyawan rendah, maka penghargaannya kecil.

5. Pemerintah dengan Undang-Undang dan Keppres

Pemerintah dengan undang-undang dan keppres menetapkan besarnya penghargaan minimum. Peraturan pemerintah ini sangat penting supaya organisasi tidak sewenangwenang menetapkan besarnya penghargaan bagi karyawan. Pemerintah berkewajiban melindungi masyarakat dari tindakan sewenang-wenang.

6. Biaya hidup

Jika biaya hidup di suatu daerah relatif tinggi, maka tingkat penghargaan semakin besar. Sebaliknya, jika tingkat biaya hidup di suatu daerah relatif rendah, maka tingkat penghargaan relatif kecil.

7. Posisi jabatan karyawan

Karyawan yang menduduki jabatan lebih tinggi akan menerima penghasilan lebih besar. Sebaliknya karyawan yang menduduki jabatan lebih rendah akan memperoleh penghasilan yang kecil.

8. Pendidikan dan pengalaman kerja

Jika pendidikan lebih tinggi dan pengalaman kerja lebih lama, maka penghargaan akan semakin besar, karena kecakapan serta keterampilannya lebih baik. Sebaliknya jika pendidikan rendah dan pengalaman kerja kurang, maka penghargaan akan semakin kecil, karena kecakapan serta keterampilannya kurang baik.

9. Kondisi perekonomian nasional

Jika kondisi perekonomian nasional booming maka tingkat penghargaan akan semakin meningkat, karena akan mendekati kondisi full employment. Sebaliknya, jika kondisi perekonomian nasional resesi, maka tingkat penghargaan akan semakin menurun.

10. Jenis dan sifat pekerjaan

Jika jenis dan sifat pekerjaan sulit dan beresiko yang besar, maka tingkat penghargaan akan meningkat karena membutuhkan kecakapan serta ketelitian untuk mengerjakannya. Sebaliknya jika jenis dan sifat pekerjaan mudah dan tidak beresiko, maka tingkat penghargaan akan lebih rendah.

Pertimbangan Pasar Kerja. Pertimbangan pasar kerja menurut Absara (2011) meliputi tersedianya lapangan kerja, keamanan kerja, fleksibilitas karir, dan kesempatan promosi sebagai berikut :

1. Tersedianya Lapangan Pekerjaan

Mahasiswa jurusan bisnis, psikologi, dan pendidikan relatif memiliki faktor jangka pendek seperti suplai kerja bidang akuntansi lebih baik dibandingkan dengan mahasiswa jurusan lainnya.

2. Keamanan Kerja

Keamanan kerja merupakan faktor di mana profesi yang dipilih dapat bertahan dalam jangka waktu yang lama. Profesi yang dipilih diharapkan bukan merupakan pilihan profesi sementara, tetapi dapat terus berlanjut sampai tiba waktu pensiun.

3. Fleksibilitas Karir

Adanya pilihan karir yang lebih fleksibel akan membantu karyawan untuk tidakberada pada situasi yang stagnasi. Karir yang fleksibel membutuhkan pengetahuan dan pelatihan yang terus menerus diperbaharui. 


\section{Kesempatan Promosi}

Promosi merupakan proses pemindahan jenjang karir secara vertikal ke arah yang lebih tinggi dan disertai dengan adanya kenaikan tanggung jawab dan imbalan. Seseorang bekerja tentu mengharapkan peningkatan posisi sesuai dengan prestasinya. Kesempatan promosi yang diberikan dapat mendorong peningkatan kualitas kerja, mewakili aspek penting dari sistem seleksi dan mengurangi turnover.

Lingkungan Kerja. Salah satu faktor yang dapat mempengaruhi produktivitas karyawan adalah lingkungan kerja. Lingkungan kerja menurut Budianas (2013) diartikan sebagai kekuatan-kekuatan yang mempengaruhi, baik secara langsung maupun tidak langsung terhadap kinerja organisasi atau perusahaan. Menurut Absara (2011) faktor-faktor yang dipertimbangkan dalam lingkungan kerja adalah sifat pekerjaan, tingat persaingan, dan banyaknya tekanan.

Berdasarkan tinjauan pustaka tersebut, maka penelitian ini merumuskan hipotesis sebagai berikut :

1. Nilai intrinsik pekerjaan berpengaruh terhadap minat mahasiswa akuntansi untuk berkarir sebagai akuntan publik.

2. Penghasilan berpengaruh terhadap minat mahasiswa akuntansi untuk berkarir sebagai akuntan publik.

3. Pertimbangan pasar kerja berpengaruh terhadap minat mahasiswa akuntansi untuk berkarir sebagai akuntan publik.

4. Lingkungan kerja berpengaruh terhadap minat mahasiswa akuntansi untuk berkarir sebagai akuntan publik.

\section{METODE PENELITIAN}

Jenis Penelitian. Penelitian ini merupakan jenis penelitian survei. Menurut Singarimbun (1955) penelitian survei adalah penelitian yang mengambil sampel dari satu populasi dan menggunakan kuesioner sebagai alat pengumpulan data yang pokok.

Populasi dan Sampling. Menurut Sugiyono (2009), populasi adalah generalisasi yang terdiri atas objek atau subjek yang memiliki kuantitas dan karakteristik tertentu yang ditetapkan oleh peneliti untuk dipelajari dan kemudian ditarik kesimpulan. Dalam penelitian ini, populasinya adalah seluruh mahasiswa Fakultas Ekonomi Akuntansi jurusan akuntansi di Universitas Sahid, Universitas Mercu Buana, dan Universitas Islam Negeri Jakarta.

Sampel adalah bagian atau anggota dari populasi (Sekaran, 2002). Menurut Arikunto (1998) sampel adalah sebagian atau wakil dari populasi yang diteliti. Adapun teknik sampling yang digunakan dalam penelitian ini adalah metode cluster sampling. Menurut Sugiyono (2009) cluster sampling adalah cara pengambilan sampel yang berdasarkan pada cluster atau kelompok tertentu. Sampel penelitian ini adalah 200 mahasiswa yang termasuk kelompok mahasiswa semester VI, VII, dan VIII karena mahasiswa pada semester tersebut sudah mengikuti mata kuliah Audit dan Metodologi Penelitian, serta diasumsikan sudah memiliki rencana karir yang akan dipilinnya.

Data dan Sumber Data. Data primer adalah data yang diperoleh langsung dari sumbernya, yaitu responden penelitian. Data primer yang dibutuhkan dalam penelitian ini meliputi nilai intrinsik, penghasilan, pertimbangan pasar kerja, dan lingkungan kerja profesi akuntan publik. 
Metode Pengumpulan Sampel. Metode ini dilakukan dengan mendatangi responden, selanjutnya memberikan kuesioner kepada responden yaitu mahasiswa fakultas Ekonomi akuntansi Universitas Sahid, Universitas Mercu Buana, Universitas Islam Negeri Jakarta, dan menanyakan kesediaan mereka untuk mengisi kuesioner. Kuesioner yang digunakan adalah pertanyaan terstruktur dan responden memberi tanda ceklis $(\sqrt{ })$ pada jawaban yang dipilih, kemudian responden mengembalikan kuesioner setelah diisi.

Variabel Penelitian. Variabel independen dalam penelitian ini adalah nilai intrinsik pekerjaan (X1), persepsi penghasilan (X2), pertimbangan pasar kerja (X3), lingkungan kerja (X4). Variabel dependen dalam penelitian ini adalah minat mahasiswa untuk berkarir menjadi Akuntan Publik. Pengukuran variabel menggunakan instrumen skala likert 1-5 point.

Metode Analisis Data. Analisis data menggunakan teknik analisis regresi linear berganda. Analisis linear berganda digunakan untuk menentukan pengaruh faktor-faktor determinan minat mahasiswa berkarir menjadi Akuntan Publik. Uji hipotesis secara parsial dianalisis berdasarkan nilai signifikansi masing-masing variabel, sedangkan uji hipotesis secara simultan dianalisis berdasarkan signifikansi nilai F. Degree of freedom yang diterapkan sebagai tolok ukur signifikansi adalah 5 persen.

\section{HASIL DAN PEMBAHASAN}

Tabel 1 berikut memberikan gambaran statistik deskriptif setiap variabel penelitian. Jumlah pengamatan dalam penelitian ini adalah 200 sampel. Variabel Nilai Intrinsik memiliki nilai minimum 20; nilai maksimum 36; nilai rata-rata 33,43; dan nilai standar deviasi sebesar 3,126 . Variabel Penghasilan memiliki nilai minimum 14; nilai maksimum 24; nilai rata-rata 22,37; dan nilai standar deviasi sebesar 02,421. Variabel Pertimbangan Pasar Kerja memiliki nilai minimum 18; nilai maksimum 32; nilai rata-rata 29,29; dan nilai standar deviasi sebesar 2,411. Variabel Lingkungan Kerja memiliki nilai minimum 6; nilai maksimum 12; nilai rata-rata 11,08; dan nilai standar deviasi sebesar 1,270. Variabel Minat Mahasiswa Berkarir sebagai Akuntan Publik memiliki nilai minimum 18; nilai maksimum 32; nilai rata-rata 28,82; dan nilai standar deviasi sebesar 2,991.

Tabel 1. Statistik Deskriptif

\begin{tabular}{lrrrrr}
\hline & N & Minimun & Maximum & Mean & Std. Deviation \\
\hline Nilai Intrinsik & 200 & 20 & 36 & 33.43 & 3.126 \\
Penghasilan & 200 & 14 & 24 & 22.37 & 2.421 \\
Pertimbangan Pasar Kerja & 200 & 18 & 32 & 29.29 & 2.411 \\
Lingkungan Kerja & 200 & 6 & 12 & 11.08 & 1.270 \\
Minat Mahasiswa & 200 & 18 & 32 & 28.82 & 2.991 \\
Valid N (listwise) & 200 & & & & \\
\hline
\end{tabular}

Sumber : data diolah.

Hasil analisis regresi linier berganda sebagaimana Tabel 2 berikut menunjukkan bahwa hanya satu variabel yang memiliki pengaruh positif terhadap minat mahasiswa berkarir sebagai Akuntan Publik. Terdapat dua variabel independen yang berpengaruh signifikan terhadap minat mahasiswa berkarir sebagai Akuntan Publik, sedangkan dua variabel lainnya tidak signifikan berpengaruh terhadap minat mahasiswa berkarir sebagai Akuntan Publik. 
Tabel 2. Analisis Regresi Linier Berganda

\begin{tabular}{lrrrr}
\hline & $\mathrm{B}$ & Std. Error & \multicolumn{1}{c}{$\mathrm{t}$} & \multicolumn{1}{c}{ Sig. } \\
\hline (Constant) & 22.655 & 3.653 & 6.201 & .000 \\
Nilai Intrinsik & -.141 & .064 & -2.187 & .030 \\
Penghasilan & -.027 & .083 & -.326 & .745 \\
Pertimbangan Pasar Kerja & .493 & .083 & 5.954 & .000 \\
Lingkungan Kerja & -.266 & .156 & -1.703 & .090 \\
\hline
\end{tabular}

Dependent : Minat Mahasiswa Berkarir sebagai Akuntan Publik.

Sumber : data diolah.

Hasil analisis regresi linier berganda tersebut menunjukkan persamaan matematis sebagai berikut :

$Y=22,655-0.141 X_{1}-0,27 X_{2}+0,493 X_{3}-0,266 X_{4}$

Variabel nilai intrinsik mempunyai nilai signifikansi lebih kecil daripada 0,05 sehingga bermakna nilai intrinsik berpengaruh signifikan terhadap minat mahasiswa berkarir sebagai Akuntan Publik. Variabel penghasilan mempunyai nilai signifikansi lebih besar daripada 0,05 sehingga bermakna penghasilan tidak berpengaruh signifikan terhadap minat mahasiswa berkarir sebagai Akuntan Publik. Variabel pertimbangan pasar kerja mempunyai nilai signifikansi lebih kecil daripada 0,05 sehingga bermakna pertimbangan pasar kerja berpengaruh signifikan terhadap minat mahasiswa berkarir sebagai Akuntan Publik. Variabel lingkungan kerja mempunyai nilai signifikansi lebih besar daripada 0,05 sehingga bermakna lingkungan kerja tidak berpengaruh signifikan terhadap minat mahasiswa berkarir sebagai Akuntan Publik.

Adapun Tabel 3 berikut menunjukkan hasil uji $\mathrm{F}$ untuk menganalisis signifikansi pengaruh seluruh variabel secara simultan. Nilai $F$ hitung sebesar 10,130 memiliki signifikansi lebih kecil daripada 0,05 sehingga mengindikasikan bahwa variabel nilai intrinsik, penghasilan, pertimbangan pasar kerja, dan lingkungan kerja secara simultan berpengaruh signifikan terhadap minat mahasiswa berkarir sebagai Akuntan Publik.

Tabel 3. Uji F

\begin{tabular}{lrrrrr}
\hline Model & Sum of Square & df & Mean Square & F & Sig. \\
\hline Regression & 306.266 & 4 & 76.566 & 10.130 & .000 \\
Residual & 1473.889 & 195 & 7.558 & & \\
Total & 1780.155 & 199 & & & \\
\hline
\end{tabular}

Dependent : Minat Mahasiswa Berkarir sebagai Akuntan Publik.

Predictors : Nilai Intrinsik, Penghasilan, Pertimbangan Pasar Kerja, Lingkungan Kerja.

Sumber : data diolah.

\section{KESIMPULAN}

Berdasarkan kajian pustaka serta anallisis hasil penelitian, dapat disimpulkan :

1. Variabel Nilai Intrinsik berpengaruh terhadap Minat Mahasiswa Berkarir sebagai Akuntan Publik.

2. Variabel Penghasilan tidak berpengaruh terhadap Minat Mahasiswa Berkarir sebagai Akuntan Publik. 
3. Variabel Pertimbangan Pasar Kerja berpengaruh terhadap Minat Mahasiswa Berkarir sebagai Akuntan Publik.

4. Variabel Lingkungan Kerja tidak berpengaruh terhadap Minat Mahasiswa Berkarir sebagai Akuntan Publik.

Diharapkan hasil penelitian ini menjadi salah satu bahan pertimbangan mahasiswa dalam memahami pilihan karir sebagai Akuntan Publik. Selain itu, juga dapat menjadi pertimbangan pihak perguruan tinggi untuk meningkatkan kerjasama praktek kerja (magang) dengan sejumlah Kantor Akuntan Publik agar mahasiswa lebih terlatih dan terarah pada profesi AKuntan Publik. Untuk penelitian selanjutnya direkomendasikan agar responden diperluas lagi, baik pada mahasiswa di perguruan tinggi negeri maupun swasta.

\section{DAFTAR PUSTAKA}

Astami, 2002. Faktor-Faktor yang Berpengaruh dalam Pemilihan Profesi Akuntan Publik dan Non Akuntan Publik bagi Mahasiswa Jurusan Akuntansi. KOMPAK 1. pp. 57-84.

Chan, A. Setiawan. 2012. Analisis Faktor-Faktor Yang Mempengaruhi Pemilihan Karir Menjadi Akuntan Publik Oleh Mahasiswa Jurusan Akuntansi. Jurnal IImiah Mahasiswa Akuntansi Vol 1, No. 1.

Harris, Lutfi dan Djamhuri, Ali. 2011. Analisis Faktor-Faktor yang Melatarbelakangi Pemilihan Karir Bagi Mahasiswa Akuntansi : Antara Akuntan Publik Versus Non Akuntan Publik. Jurnal Aplikasi Manajemen Vol 11. Universitas Brawijaya.

Kuningsih. 2013. Faktor-Faktor yang Mempengaruhi Niat Mahasiswa Akuntansi Untuk Berkarir Sebagai Akuntan Profesional. Skripsi. Semarang: Universitas Diponegoro.

Puspita, Devi. 2011. Pengaruh Persepsi Mahasiswa Tentang Profesi Guru dan Prestasi Belajar Terhadap Minat Menjadi Guru. Fakultas IImu Sosial dan Ekonomi Universitas Negeri Yogyakarta.

Rahayu, Sri, dkk. 2003. Persepsi Mahasiswa Akuntansi Mengenai Faktor-Faktor yang Mempengaruhi Pemilihan Karir. Simposium Nasional Akuntansi VI. pp. 821-837.

Sulistyani. 2012. Faktor-Faktor yang Mempengaruhi Minat Mahasiswa Akuntansi Untuk Berkarir Menjadi Akuntan Publik. Skripsi. Universitas Negeri Yogyakarta

Widyasari, Yuanita. 2010. Persepsi Mahasiswa Akuntansi Mengenai Faktor-Faktor yang Membedakan Pemilihan Karir. Skripsi. Universitas Diponegoro. 